Jan P. Strumiłowski OCist

0000-0003-1547-8309

Wyższe Seminarium Duchowne

w Katowicach-Panewnikach

DOI: $10.15290 /$ std.2018.04.06

\title{
NEURONAUKI, TEOLOGIA, METAFIZYKA - W POSZUKIWANIU WSPÓLNEJ PRZESTRZENI DIALOGU
}

\section{NEUROSCIENCE, THEOLOGY, AND METAPHYSICS: SEEKING A COMMON GROUND FOR DIALOGUE}

The present article focuses on the role of metaphysics in the dialogue between neuroscience and theology in order to determine an ontology of the soul that neuroscience finds acceptable and consistent. Theological discourse on the human person or soul necessitates that one enter into the field of metaphysics - a field into which neuroscience, in principle, does not venture.

By considering several variants of the metaphysical spaces of dialogue, this article first attempts to determine whether dualistic interpretations work and then presents the potential problems associated with the approach of these interpretations. It then proceeds to consider whether theological anthropology can be carried out using a monistic key. To this end, the author analyzes the anthropological content of Revelation as well as the statements of the Magisterium of the Church from a metaphysical point of view.

The end of the article presents a relational concept of the soul that appears to address the issue of dualism while simultaneously upholding basic theological postulates (such as the immortality of the person and the mortality of the body), despite the argument that an ontological status that guarantees human subjectivity cannot be ascribed to the soul.

Key words: neuroscience, theology, anthropology, metaphysics, soul, immortality, relationship. 


\section{Wstęp}

Szybki rozwój naukowy, który mogliśmy obserwować w XX wieku i który wciąż obserwujemy wydaje się rodzić coraz większy rozdźwięk między myśleniem naukowym i myśleniem religijnym. Świadectwem narastającego konfliktu są coraz liczniejsze publikacje zarówno o charakterze naukowym jak i popularnonaukowym dotykające kwestii związku religii z nauką, przy czym tymi, którzy wskazują na brak integracji zazwyczaj są badacze z kręgu nauk empirycznych, zorientowani ateistycznie ${ }^{1}$, zaś tymi, którzy starają się wskazać na możliwość istnienia jednej, spójnej wizji świata, respektującej zarówno założenia teologiczne jak i odkrycia naukowe są teolodzy, bądź naukowcy, dla których wiara jest czymś istotnym w ich życiu. Wątpliwości dotykające naukowców nie omijają oczywiście także wiernych, na których współczesna myśl naukowa niewątpliwie oddziałuje.

Niewątpliwie w dzisiejszych czasach bardzo dynamicznie rozwijającą się gałęzią nauk, które mocno wpływają na utrwalone w tradycji religijnej spojrzenie na człowieka są neuronauki, na gruncie których próbuje się badać biologiczne korelaty wszelkich aktywności człowieka, nie wyłączywszy sfery religijnej, przez co neuronauki wydają się w sposób naturalny przyłączać do debaty antropologicznej. Co więcej, tezy neuronaukowców w tejże debacie wydają się stać w pewnej opozycji względem tez antropologii teologicznej.

Kontrowersje na styku neuronauk i antropologii teologicznej szczególnie wiążą się z opartym na odkryciach neuronauk kwestionowaniem zasadności chrześcijańskiej tezy o istnieniu duszy, która jest centrum oraz nośnikiem życia i tożsamości człowieka. Według wielu badaczy odkrycia neurobiologicznego podłoża funkcji postrzeganych dotąd jako przynależne do sfery duchowej, prowadzą do oczywistego wniosku, jakoby hipoteza duszy była zbędna, gdyż badania neuronauk wydają się dowodzić, iż wszelkie procesy związane z ludzką

1 W ostatnich czasach ukazuje się coraz więcej pozycji, które na kanwie tez naukowych próbują skompromitować tezy religijne, np. zob. R. Dawkins, Bóg urojony, tłum. P. Szwajcer, Wydawnictwo CiS, Warszawa 2007; R. Dawkins, Ślepy zegarmistrz czyli jak ewolucja dowo$d z i$ że świat nie został zaplanowany, tłum. A. Hoffman, Państwowy Instytut Wydawniczy, Warszawa 1997; V. J. Stenger, God: the failed hypothesis; how science shows that good does not exist, Prometheus Books, Amherst - New York 2008; D.C. Dennett, Odczarowanie: religia jako zjawisko naturalne, tłum. B. Stanosz, Państwowy Instytut Wydawniczy, Warszawa 2013.

2 Tożsamość osoby wydaje się być stabilna - człowiek pozostaje sobą pomimo upływającego czasu i zmian, jakie w nim zachodzą. Niemniej tożsamość osoby ściśle wiąże się $z$ tożsamością osobowości, która już się zmienia, por. J. Bremer, Jaźń i tożsamość osobowa, [w:] Przewodnikpo filozofii umystu, M. Milkowski, R. Poczobut (red.), Wydawnictwo WAM, Kraków 2012, s. 430-431. 
tożsamością swoją genezę odnajdują w strukturze i pracy mózgu³. Zatem jak mówią sami - duszy nie ma, jest tylko mózg ${ }^{4}$.

Teza lokalizująca podłoże władz typowo ludzkich (rozum, wola, pamięć) w mózgu, a nie w duszy, na pierwszy rzut oka uderza w teologiczną wizję. Jeśli bowiem owe władze są kwestią jedynie biologii (cielesności) to powstaje pytanie, w jaki sposób ludzka tożsamość, która jest z nimi związana, może trwać po śmierci? Zasadnicze pytanie, które winien zadać sobie teolog w obliczu odkryć neuronaukowych brzmi zatem: czy wraz z rozpadem biologicznego podłoża nie ulega rozpadowi jaźń, świadomość i tożsamość? Czy odkrycia neuronauk dotykające zagadnienia biologicznych komponentów pamięci, wolnej woli czy rozumności faktycznie nie sprawiają, że hipoteza nieśmiertelnej duszy wydaje się być obalona, natomiast tajemnicę człowieka można opisać w kluczu neurobiologicznym bez uciekania się do twierdzeń teologicznych?

Spoglądając na ów problem z innej perspektywy, można stwierdzić, że podczas gdy neuronauki starają się wyjaśnić tajemnicę człowieka oraz działania typowo ludzkich procesów w sposób naturalny, poprzez rozumienie wszelkich procesów umysłowych jako pewnego rodzaju skutków lub pochodnych działania mózgu, teologia, ze względu na swoje tezy eschatologiczne (nieśmiertelność i trwanie ludzkiego „ja” pomimo śmierci ciała), wydaje się z konieczności przyjmować istnienie sfery nadprzyrodzonej, innej niż sfera cielesna. Co więcej, ze względu na fakt, że owa sfera w tradycji antropologii teologicznej zdefiniowana jest w ten sposób, że jest podstawą wymienionych wyżej władz duchowych oraz, co się z tym wiąże, stanowi podstawę istnienia ludzkiej tożsamości pomimo śmierci ciała, wydaje się, że z konieczności tak rozumiana dusza musi posiadać szczególny status ontologiczny. Jeśli bowiem dusza jest zdefiniowana jako sfera duchowa inna niż ciało, ponadto jako element pozwalający trwać ludzkiemu „ja” pomimo śmierci ciała, to wydaje się że musi ona posiadać status ontologiczny, który może stanowić podstawę ludzkiej podmiotowości. Dialog między neuronaukami a teologią z konieczności zatem angażuje od strony teologicznej podjęcie debaty na gruncie metafizycznym. Wydaje się bowiem, że główna oś zarysowanego sporu wynika $z$ faktu, że neuronaukowa wizja świata z założenia

Zob, W.S. Brown, N.C. Murphy, H.N. Malony, Whatever Happened to the Soul? Scientific and Theological Portraits of Human Nature, Fortress Press, Minneapolis 1998; J.B. Green, What About the Soul?: Neuroscience and Christian Anthropology, Abingdon Press, Nashville 2004; E.L. Johnson, Whatever Happened to the Human Soul? A Brief, Christian Genealogy of a Psychological Term, "Journal of Psychology and Theology", 1998, t.26, nr 1, s. 1628; P.D. Miller, Whatever Happened to the Soul?, "Theology Today", 1994, t.50, nr 4, s. 507-510.

4 Zob. S. Zeki, Neurologia wieloznaczności, [w:] Formy aktywności umystu: ujęcia kognitywistyczne, t. 2, A. Klawiter (red.), tłum. A. Gruszka, Wydawnictwo Naukowe PWN, Warszawa 2009, s. 445. 
poszukuje wyjaśnienia, które na gruncie filozoficznym kategoryzowane są jako ujęcia materialistyczne lub względnie monistyczne ${ }^{5}$. Tymczasem teologia ze względu na swoje tezy eschatologiczne $z$ konieczności wydaje się zakładać pewnego rodzaju dualistyczną wizję świata ${ }^{6}$. Czy jednak prowadzenie dialogu $z$ neuronaukami na gruncie metafizycznym jest w ogóle możliwe?

\section{Neuronauki a metafizyka}

Neuronauki z założenia są neutralne metafizyczne. W swoich założeniach przyjmują posługiwanie się naturalizmem metodologicznym, co oznacza, że w kręgu ich zainteresowań nie znajdują się żadne byty supernaturalne (w tym również dusza). Neuronauki interesują się samym funkcjonowaniem ${ }^{7}$ systemu poznawczego. $Z$ takiego założenia wynikają co najmniej dwa wnioski. Po pierwsze, neuronauki nie są w stanie obalić tezy o istnieniu duszy, ani w ogóle nie są w stanie stwierdzić, że postrzeganie świata w konwencji dualistycznej jest błędne, chociaż same takiego punktu widzenia nie mogą przyjąć. Zdarza się oczywiście, że neuronaukowiec na podstawie swoich badań dokonuje sądów metafizycznych, lecz w takim wypadku należy jasno podkreślić, że wychodzi on $z$ roli naukowca, a wchodzi w rolę filozofa. Niemniej wskazywanie na jednoznaczne wnioskowanie tezy o nieistnieniu świata nadprzyrodzonego z badań naukowych jest poważnym błędem. W takim wnioskowaniu dochodzi bowiem do niedopuszczalnego utożsamienia słusznego skądinąd naturalizmu metodologicznego $z$ naturalizmem ontologicznym. W procesie tym z samych założeń nauk empirycznych, wyciąga się wnioski ontologiczne ${ }^{8}$. Po drugie, przyjęcie naturalizmu metodologicznego jako założenia sprawia, że same wyniki badań poddają się interpretacji metafizycznej, w tym także interpretacji przyjmującej konwencję dualistyczną9. Sama interpretacja jest już jednak właściwym przedmiotem filozofii.

$5 \quad$ Neuronauki ze względu na założenia metodologiczne nie mogą w swoich wyjaśnieniach poszukiwać wyjaśnień i rozwiązań innych niż wyjaśnienia naturalistyczne.

6 Oczywiście nie chodzi tutaj o skrajne ujęcia dualizmu substancji w rodzaju platonizmu lub kartezjanizmu. Skrajny dualizm z teologicznego punktu widzenia jest równie problematyczny co materializm.

7 Por. A. Chuderski, Wykorzystanie metod sztucznej inteligencji w badaniach nad umystem, 3.06.2002, http://www.kognitywistyka.net/artykuly/ach-wmsiwnu.pdf, 27.02.2017.

8 Por. T. Pabjan, Anatomia konfliktu: Między nowym ateizmem a teologia nauki, Copernicus Center Press, Kraków 2016, s. 52-53.

9 Współcześnie zwolennikami dualistycznych interpretacji są np. K. Popper i J. Eccles, zob. K.R. Popper, J.C. Eccles, The self and its brain, Routledge, London 1990. 
Trzeba nam jednak stwierdzić, że pomimo istnienia takiej możliwości, przyjęcie metafizycznej przestrzeni dualizmu jest problematyczne w kwestii dialogu z naukami. Dzieje się tak przede wszystkim ze względu na różne trudności, jakie wprowadza w ów dialog założenie dualizmu. Wśród najważniejszych argumentów stanowiących krytykę dualizmu należy wymienić problem z deskrypcją substancji mentalnej, problem $z$ satysfakcjonującym i naukowym opisem interakcji, niezgodność każdego rodzaju interakcji z zasadą domknięcia dziedziny fizycznej, możliwość wyjaśnień jedynie fizykalnych w innych dziedzinach nauki, co stanowi prognostyk również dla nauk o umyśle, niezgodność z teorią ewolucji1 ${ }^{10}$. Z perspektywy niniejszej pracy najważniejszy argument sprowadza się jednak do wniosków zaczerpniętych z postępu badań nad neuronowymi korelatami zdarzeń mentalnych oraz zarzut metodologiczny, wskazujący, że dualizm faktycznie jest z założenia nienaukowy, natomiast utrzymywany jest w celu obrony w świetle odkryć naukowych równie nienaukowej tezy o nieśmiertelności duszy. $\mathrm{Z}$ tego też względu sama teza o istnieniu substancji duchowej wydaje się być $z$ naukowego punktu widzenia zbędna ${ }^{11}$.

W tak zarysowanym kontekście dialogu uzasadnione wydaje się pytanie, czy $z$ teologicznego punktu widzenia możliwe jest obranie perspektywy bardziej monistycznej (która byłaby mniej problematyczna ze względu na respondenta, jakim są nauki)? Czy możliwe jest mówienie o duszy w taki sposób, by nie traktować jej jako czegoś potencjalnie oderwanego od ciała, co posiada status ontologiczny tak zdefiniowany, by mogła ona być przestrzenią lub miejscem partycypacji ludzkiego „ja”? Czyli, ujmując inaczej tej kwestię zapytać należy, czy możliwe jest takie myślenie o duszy, by nie przydawać jej charakteru podmiotowości?

W tym celu odpowiedzieć należy $z$ teologicznego punktu widzenia na bardziej podstawowe pytanie, mianowicie: czy narracja metafizyczna, zwłaszcza dualistyczna należy do depozytu wiary, czy może stanowi jedynie konwencję narracji prawdy objawionej, a jeśli jest to tylko konwencja, to na ile jest ona konieczna do wyrażenia pełni prawdy antropologiczno-teologicznej?

\footnotetext{
10 Por. M. Iwanicki, Dualizm psychofizyczny: odmiany, argumenty, zarzuty, [w:] Przewodnik po filozofii umystu, M. Miłkowski, R. Poczobut (red.), Wydawnictwo WAM, Kraków 2012, s. 68.

11 Por. ibidem, s. 68-69.
} 


\section{Antropologia teologiczna a metafizyka}

W chrześcijańskiej narracji na temat duszy (spoglądając na genezę tej narracji) możemy rozpoznać dwie tendencje: grecką ${ }^{12}$ i semicką. Grecka, ujmująca duszę w znaczeniu substancji (na różny sposób rozumianej) kładzie nacisk na stabilność, trwałość i ciągłość w procesie stawania się człowieka ${ }^{13}$. Semicka tymczasem ujmuje duszę jako moc, siłę ożywczą ciała, chcąc w ten sposób pokazać konkretną egzystencję w jej ekspresji ${ }^{14}$. Brak substancjalnego określenia sprawia, że w ujęciu semickim dusza nie jest czymś, co jest przydane człowiekowi, ale bardziej słusznie należy powiedzieć, że człowiek jest duszą, podobnie jak słuszne jest powiedzenie, że człowiek jest ciałem ${ }^{15}$. Semici myśląc o człowieku, nie czynią tego w obrębie jakiegokolwiek dualizmu. Posługując się terminami takimi jak ciało, dusza, czy serce nie zwracają uwagi na pewną część czy sferę bytu ludzkiego, lecz patrzą na człowieka pod pewnym aspektem ${ }^{16}$. Podobne tendencje, aczkolwiek już z obecnymi naleciałościami myśli greckiej, zachowuje Nowy Testament ${ }^{17}$.

To rozróżnienie sprawia, że chociaż teksty teologiczne obciążone są ładunkiem metafizycznym - i to różnie zdefiniowanym (wśród pism Ojców Kościoła możemy znaleźć teksty antropologiczne przyjmujące zarówno konwencję dualistyczną jak i monistyczną ${ }^{18}$ ), współcześnie często wskazuje się, że nie ma konieczności w stosowaniu w antropologii teologicznej podziału na dwie oddzielne substancje ( $\mathrm{w}$ znaczeniu ontologicznych uwarunkowań trwania podmiotowości) w celu utrzymaniu tradycyjnej nauki katolickiej ${ }^{19}$, przy czym teolodzy stawiając taką tezę podkreślają, że dualistyczne naleciałości w teologii pochodzą z kręgów myśli filozoficznej i jako takie nie stanowią istotnych elementów konstytutywnych antropologii chrześcijańskiej. Skoro podstawowe

12 Por. A.H. Armstrong, R.A. Markus, Wiara chrześcijańska a filozofia grecka, tłum. H. Bednarek, Instytut Wydawniczy PAX, Warszawa 1964, s. 56.

13 Por. G. Martelet, Odnalezione życie wieczne, tłum. M. Krzeptowska, Wydawnictwo WAM, Kraków 2000, s. 21.

14 Por. ibidem

15 Por. C. Tresmontant, Esej o myśli hebrajskiej, tłum. M. Tarnowska, Wydawnictwo Znak, Kraków 1996, s. 116.

16 Por. J.L. Ruiz de La Peña, Umysty, mózgi, maszyny, [w:] Kosmos i człowiek, t. 4, Wydawnictwo Pallottinum, Poznań - Warszawa 1989, s. 169.

17 Por. M. Składanowski, Ciało, dusza, duch. Myśl Josepha Ratzingera na tle wspótczesnej antropologii, Wydawnictwo Sióstr Loretanek, Warszawa 2013, s. 37.

18 Por. ibidem, s. 38-44.

19 Por. J. Bremer, Wprowadzenie do filozofii umystu, Wydawnictwo WAM, Kraków 2010, s. 38-45. 
źródło prawdy objawionej dystansuje się od orzeczeń natury metafizycznej, to możliwe jest również takie dystansowanie się w obrębie teologii.

Dla teologii jednak wiążące są nie tylko teksty biblijne, ale też teksty $\mathbf{M a}$ gisterium. Dlatego też dla prawidłowego określenia właściwej antropologii teologicznej przestrzeni metafizycznej lub ewentualnie możliwości jej braku, winniśmy pod tym kątem przyjrzeć się również tekstom Magisterium Ecclesiae.

Najbardziej problematyczne z metafizycznego punktu widzenia wydają się być wypowiedzi Soboru w Vienne o substancjalności i samoistności duszy. Sobór w Vienne stwierdza, że substancja duszy rozumnej, czyli intelektualnej jest sama przez się i ze swej istoty formą ludzkiego ciała ${ }^{20}$. W wypowiedzi tej zawarta jest zarówno teza o duszy rozumianej jako forma ciała, jak i o jej istotowej odrębności lub nietożsamości względem niego. Akcent na ten drugi aspekt kładzie mocno również konstytucja Benedictus Deus Benedykta XII orzekając o istnieniu duszy po śmierci ciała, przed jego zmartwychwstaniem ${ }^{21}$. Podobnie Sobór Laterański V potępia każdego kto mniema, że dusza ludzka jest śmiertelna, lub jedna dla wszystkich ludzi. Dalej zaznacza, że jest ona sama $z$ siebie i ze swej istoty formą ludzkiego ciała oraz elementem gwarantującym życie wieczne ${ }^{22}$. Ponadto, Sobór stwierdza, że wielość dusz wynika z faktu, że „stosownie do ilości ciał, z którymi się łączy, każdorazowo jest pomnażalna, pomnażana i mająca być pomnożoną" ${ }^{23}$.

Nim przejdziemy do analizy metafizycznych interpretacji owych orzeczeń warto przyjrzeć się bardziej współczesnym narracjom magisterialnym, Współcześnie zaobserwować możemy bowiem większą ostrożność względem takich określeń duszy, które mogłyby sugerować zupełną autonomię i odrębność względem ciała. Konstytucja Lumen gentium II Soboru Watykańskiego określa

20 Por. Sobór w Vienne, Dekrety, [w:] Dokumenty Soborów Powszechnych: tekst grecki, łaciński, polski, t. 2, A. Baron, H. Pietras (red.), tłum. A. Baron, H. Pietras, T. Wnętrzak, Wydawnictwo WAM, Kraków 2003, s. 532-533.

21 Por. Benedykt XII, Konstytucja „Benedictus Deus”, [w:] Breviarium fidei: wybór doktrynalnych wypowiedzi Kościoła, red. I. Bokwa, Księgarnia Świętego Wojciecha, Poznań 2007, nr 263.

22 Por. Sobór Laterański V, Sesja 8 (piątek 5 maja 1513): I. Potępienie wszelkich twierdzeń sprzecznych z prawda chrześcijanskiej wiary objawionej na temat duszy ludzkiej, [w:] Dokumenty Soborów Powszechnych: tekst grecki, łaciński, polski, t. 4, A. Baron, H. Pietras (red.), tłum. A. Baron, H. Pietras, A. Caba, Wydawnictwo WAM, Kraków 2003, nr 3-4.

23 Ibidem. Zapis o fakcie pomnażania duszy przy połączeniu z ciałem, sugeruje jakoby była ona rozumiana jako Boska i jedna zasada życia, która w akcie stwórczym, staje się formą ciała i nieśmiertelną zasadą życia. 
np. duszę po prostu jako zasadę życia ${ }^{24}$, przez co wydaje się nawiązywać do źródłowego myślenia biblijnego, a konstytucja Gaudium et spes podkreśla jedność duszy i ciała w człowieku ${ }^{25}$.

Pewne ryzy na zbyt swobodną interpretację metafizyczną wydaje się nakładać Kongregacja Nauki Wiary w dokumencie na temat niektórych kwestii eschatologicznych, w którym stwierdza że

Kościół przyjmuje istnienie i życie, po śmierci, elementu duchowego, obdarzonego świadomością i wolą w taki sposób, że „ja ludzkie” istnieje nadal, chociaż w tym czasie brakuje dopełnienia jego ciała. Na oznaczenie tego elementu Kościół posługuje się pojęciem „duszy”, którego używa Pismo Święte i Tradycja. Chociaż pojęcie to ma w Biblii różne znaczenia, Kościół stwierdza jednak, że nie ma poważnej racji, by je odrzucić, a co więcej, uważa, że jest bezwzględnie konieczny jakiś aparat pojęciowy dla podtrzymywania wiary chrześcijan"26.

Powyższe teksty wskazują zatem na trzy kwestie, które są kluczowe w teologicznym rozumieniu metafizyki duszy, chodzi mianowicie o jej substancjalność, samoistność oraz trwanie pomimo śmierci ciała. Te trzy tezy wydają się sugerować ujęcie dualistyczne jako preferencyjne. Czy jednak owe teksty Magisterium faktycznie upatrywały w swoich formułach metafizycznie zdefiniowany dualizm, czy jest to raczej nadinterpretacja wynikająca ze zdeformowanego, pokartezjańskiego sposobu myślenia?

Współcześnie faktycznie słowo substancjalność kojarzy się z tym co materialne, z podmiotowością, czyli rozumie się je spontanicznie na sposób fizykalny a nie metafizyczny ${ }^{27}$. Tymczasem słowo to w orzeczeniach Magisterium zapożyczone zostało ze słownika metafizyki Tomasza z Akwinu. Tomasz natomiast nie rozumiał jej na sposób bytu lub podmiotu ${ }^{28}$. Przede wszystkim zaznaczyć

24 Por. Sobór Watykański II, Konstytucja dogmatyczna o Kościele „Lumen gentium”, [w:] Konstytucje, dekrety, deklaracje, Sobór Watykański II, Wydawnictwo Pallottinum, Poznań 2002, nr 7.

25 Por. Sobór Watykański II, Konstytucja duszpasterska o Kościele „Gaudium et spes”, [w:] Konstytucje, dekrety, deklaracje, Sobór Watykański II, Wydawnictwo Pallottinum, Poznań 2002, nr 3 i 14 .

26 Kongregacja Nauki Wiary, List do biskupów o niektórych zagadnieniach dotyczacych eschatologii „Recentiores episcoporum Synodi”, [w:] W trosce o petnię wiary. Dokumenty Kongregacji Nauki Wiary 1966-1994, J. Królikowski (red.), tłum. J. Królikowski, Z. Zimowski, Wydawnictwo Biblos, Tarnów 1979, s. 150.

27 Por. T. Rutowski, Pojęcia materii na terenie filozofii i fizyki, „Studia Philosophiae Christianae", 1968, t. 23, nr 1, s. 75-96.

28 Niestety w ten sposób bardzo często o duszy orzeka się, określając ją wprost jako byt, lub jako zasadę bytową, która tkwi w ciele i istnieje dalej jako człowiek (względnie - osoba) pomimo śmierci ciała, co jest wynikiem myślenia platonizującego i to w takiej wersji, która redukuje postulaty biblijne na temat istnienia duszy. Ujęcie takie w kręgach chrześcijańskich 
należy, że dusza w ujęciu Tomasza nie jest osobą, tzn. że „ja” tożsamościowe nie jest duszą, a dusza oddzielona od ciała nie jest siedliskiem tożsamości, które jest po prostu w życiu doczesnym zamknięte w ciele. Tomasz daje temu wyraz w twierdzeniu, że osoba ludzka w ogóle nie może istnieć poza ciałem. O tożsamości człowieka stanowi zatem cały byt ludzki, przy czym dusza, będąca formą ciała jest po prostu jego życiem ${ }^{29}$. Tomasz nie kojarzył więc tożsamości człowieka $z$ jakimkolwiek pierwiastkiem duchowym ${ }^{30}$. Duszę rozumie więc Tomasz jako konkretny sposób w jakim coś żyje. Zatem dusza intelektualna nie świadczyła o partycypowaniu pierwiastka duchowego, który ożywionemu ciału przydaje osobowości i podmiotowości. Dusza intelektualna świadczy, że człowiek żyje na sposób intelektualny, czyli osobowy, rozumny. Życie człowieka, życie owej materii stanowiącej byt ludzki jest życiem osobowym, a ta osobowość powodowana jest przez duszę, która ową materię właśnie w taki, rozumny, ludzki byt konkretyzuje ${ }^{31}$. Jak zatem określa to D. Turner, streszczając pogląd Tomasza na temat duszy jako formy życia konkretnego bytu, „ludzka dusza jest tym, co sprawia, że to konkretne ciało jest ciałem, a w szczególności ludzkim ciałem, i żyje tak, jak to jest właściwe ludziom"32.

Określając duszę mianem substancji Tomasz podkreśla zatem jej właściwość rozumianą w metafizycznym pojęciu formy. Określenie jej mianem substancjalnej formy oznacza zatem nie tyle jej podmiotowy charakter, ale oznacza, że owa forma nie jest własnością immanentną materii (ciała), nie jest jej epifenomenem, nie wyłania się z niej, ale raczej jest czymś co nadaje materii określenie i konkretny sposób istnienia.

Podobnie rzecz ma się z samoistnością. Stosując określenie samoistności nie podkreśla Tomasz jej odrębnego istnienia i egzystowania poza ciałem, ale

filozofów jest bardzo powszechne, zob. np. P. Liszka, Dusza ludzka: substancja duchowa czlowieka, Wydawnictwo Tum, Wrocław 2017. Jeszcze bardziej powszechne jest orzekanie o duszy jako o bycie przy respektowaniu arystotelesowsko-tomistycznego hylemorfizmu, czyli przy założeniu, że dusza ściśle rzecz ujmując bytem samym w sobie nie jest, aczkolwiek przy mocnym zaakcentowaniu jej odrębności sugerującej pewną formę niezależności quasi-bytowej, zob. np. S. Kowalczyk, Idea duszy w refleksji filozoficznej, Wydawnictwo KUL, Lublin 2016; R. Darowski, Filozofia cztowieka: zarys problematyki, Wydawnictwo WAM, Kraków 2015. Ogólną panoramę różnych denominacji owego pojmowania substancjalności i odrębności prezentuje T. Wojciechowski, zob. T. Wojciechowski, Zagadnienie substancjalności duszy ludzkiej w ujęciu ewolucyjnym, „Roczniki Filozoficzne”, 1980, t. 28, nr 3, s. 147-148. Instytut Tomistyczny, Poznań - Warszawa 2017, s. 74.

Por. ibidem, s. 75.

31 Por. ibidem, s. 78-79.

32 Ibidem, s. 79. 
stwierdza, że owo życie, które jest funkcją duszy znowu nie jest epifenomenem ciała, nie jest funkcją lub właściwością ożywionych tkanek. Mówiąc językiem Tomasza, ciało nie jest więc warunkiem istnienia duszy, ale jest warunkiem jej ujednostkowienia, czyli aktualizacji i indywidualizacji w konkretnym człowieku ${ }^{33}$. O samoistności duszy (o tym, że może działać ona sama przez się) świadczy natomiast fakt, że uczestniczy ona w istnieniu ${ }^{34}$. Zatem samoistność duszy nie świadczy o jej autonomii bytowej, ale świadczy raczej o metafizycznym charakterze istnienia, w którym dusza uczestniczy, a które aktualizuje się w materii za jej pośrednictwem. Dusza jest zasadą aktualizacji ciała (jest jego aktem) tworząc byt ludzki w taki sposób, że to ona jest zasadą organizacji materii w formę bytu ludzkiego, natomiast zasadą jednostkowości duszy, rozumianej jako zasada życia cielesnego (życie konkretnego ciała) jest w takim układzie konkretne jednostkowe ciało ${ }^{35}$.

Reasumując, możemy stwierdzić, że zarówno substancjalność jak i samoistność nie świadczą o tym, jakoby dusza mogła istnieć bez ciała na sposób ontologicznej podmiotowości. Pojęcia te świadczą o metafizycznym charakterze życia i istnienia oraz formy ciała, tzn. że nie są one funkcjami ciała z niego się wyłaniającymi, lecz są przydane ciału - są one względem niego nadrzędne. W jaki sposób jednak możemy rozumieć duszę, nie pojmując jej jako czegoś w rodzaju bytu, posiadającego ontologiczny status podmiotowości?

\section{Relacyjna koncepcja duszy}

Zgodnie z powyższymi określeniami duszy ludzkiej, powinniśmy ją z jednej strony pojmować jako całkowicie przynależną materii (jest formą ciała), a z drugiej jako element iście duchowy, aczkolwiek nie stanowiący o podmiotowości (dusza nie jest bytem i nie posiada ontologicznego statusu podmiotowości). Innymi słowy dusza jest w człowieku ściśle zjednoczona z ciałem, tak, że w pełni można określić ją mianem formy, a ta forma jest tym, co człowieka czyni osobą ${ }^{36}$.

33 Por. M. Seckler, Zbawienie w historii. Teologia historii wnauce świętego Tomasza z Akwinu, tłum. W. Szymona, Fundacja „Dominikańskie Studium Filozofii i Teologii”: Kolegium Filozoficzno-Teologiczne Polskiej Prowincji Dominikanów, Kraków 2015, s. 176.

34 „Quaecumque autem forma creata per se subsistens ponatur, oportet quod prticipet esse: quia etiam ipsa vita, vel quidquid sic diceretur, participat ipsum esse”, por. Tomasz z Akwinu, Summa teologiczna: Traktat o człowieku I, 75-89, tłum. S. Swieżawski, Wydawnictwo Antyk, Kęty 1998, nr I, 75, q. 1, a. 5.

35 Por. ibidem, nr I, q. 75, a. 4.

36 Por. J. Ratzinger, Eschatologia - śmierć $i$ życie wieczne, [w:] Zmartwychwstanie $i$ życie wieczne. Studia o eschatologii $i$ teologii nadziei, tłum. J. Kobienia, Wydawnictwo KUL, Lublin 2014, s. 150-151. 
Wydaje się, że tak zdefiniowany charakter duszy może być zachowany również przy jej relacyjnym rozumieniu, jakie zaproponował J. Ratzinger ${ }^{37}$. Dusza tak rozumiana jest odniesieniem bytu ludzkiego do Boga i to odniesieniem dwukierunkowym. Po pierwsze, jest odniesieniem stwórczym (Bóg określa czym/kim jest człowiek) stwarzając go, a to odniesienie jest niezbywalne, ale też człowiek jest odniesiony do Boga, czyli poznaje Go, sięga relacji z Nim, co stanowi w gruncie rzeczy gwarancję życia wiecznego ${ }^{38}$. Bóg w ten sposób jest tym, który stwarzając człowieka określa jego istotę i istnienie, czyli jest autorem ludzkiej tożsamości, a tożsamość ta jest zdefiniowana jako tożsamość istoty rozumnej i wolnej, co stanowi o podobieństwie człowieka do Boga. Bóg stwarzając człowieka zapoczątkowuje zatem z nim relację, w której nadaje mu istnienie istoty podobniej do Niego (formę ciała ludzkiego) oraz urzeczywistnia tę relację udzielając człowiekowi istnienia i życia.

Ze względu na charakter owej relacji wydaje się już być zabezpieczona prawda o życiu wiecznym. Relacja, której inicjatorem jest Bóg - ze względu na nieodwołalność Jego miłości jest relacją wieczną. Ludzkie istnienie (ludzka bytowość i podmiotowość) jest skutkiem tej relacji. Zatem możemy się spodziewać, że nawet po zniszczeniu (śmierci) ludzkiego podmiotu, w eschatonie zostanie ona dopełniona ze względu na niezbywalność samej relacji. Ponadto owa relacja określając człowieka jako istotę rozumną i wolną, świadczy o tym, że człowiek jest stworzony jako istota zdolna do relacji, a więc zdolna do odwzajemnienia owej Boskiej miłości, do wejścia w relację z samym Bogiem („,podobna” do Boga). Sama relacja zaś, z teologicznego punktu widzenia posiada status ontologiczny (w Bogu relacje są ontologicznie równe hipostazom, dlatego też hipostazy możemy określić jako relacje samoistne ${ }^{39}$ ), co oznacza, że elementem konstytuującym hipostazę w jej istocie jest właśnie relacja. Należy oczywiście pamiętać tutaj o różnicy relacji wewnątrztrynitarnych oraz relacji stwórczej, która jest relacją ad extra. Niemniej działanie to (relacja) jest pewnego rodzaju przedłużeniem działania ad intra ${ }^{40}$, które jest wzorem i probierzem działania Boga na zewnątrz. Różnica ta sprawia, że skutkiem tej drugiej relacji jest byt, który nie posiada natury boskiej, aczkolwiek sama relacja może być dzięki tej zależności rozumiana jako pierwiastek duchowy i stworzony (ad extra),

37 Por. ibidem, s. 150-154.

38 Por. ibidem, s. 152-154.

39 Por. Tomasz z Akwinu, Suma teologiczna, tłum. S. Bełch, Veritas, Londyn 1962, s. I, q. 29, a. 4 .

40 Por. C. Smuniewski, Wspólnota laski: charytologiczno-trynitarna eklezjogeneza, Wydawnictwo WAM, Kraków 2013, s. 186. 
chociaż sama w sobie nie posiada statusu podmiotu - podmiotowość ludzka jest skutkiem relacji.

\section{Wnioski}

Zdefiniowana w ten sposób relacyjna koncepcja duszy, ze względu na charakter tejże relacji pozwala nam na wyciągnięcie następujących wniosków na temat jej natury, które wydają się być zgodne z tradycyjnym jej rozumieniem, a która nie prowadzi z konieczności do ujmowania antropologii teologicznej w konwencji dualizmu substancji:

1. Relacja owa może być pojmowana jako element nadprzyrodzony, lecz stworzony (ad extra).

2. Jest ona elementem określającym człowieka w jego tożsamości, czyli konstytuującym ludzkie „ja”, co czyni ją znaczeniowo równą formie ciała.

3. Gwarantuje ona życie wieczne pomimo śmierci ciała (relacja jest istotowo pierwotna względem ludzkiej podmiotowości).

4. Nie posiada statusu podmiotowości, tzn. nie jest bytem ani podstawą podmiotowości, aczkolwiek posiada status ontologiczny, który stanowi o określeniu człowieka w jego konstytucji psycho-fizycznej. Takie rozumienie duszy sprawia, że pozwala ona na pozostawienie pełnej autonomii neuronaukom badającym tę właśnie konstytucję. Teologia dopowiada w tym miejscu natomiast, że sama ta konstytucja jest ufundowana teologicznie (przez Boga).

5. Dusza tak zdefiniowana jest elementem nadrzędnym względem ciała, przez co zgodnie z tradycyjną nauką cieszy się supremacją względem niego (redukuje to utożsamienie jej z epifenomenami ciała, które podlegają kompetencjom badawczym nauk.

6. Jest elementem określającym człowieka jako istotę podobną do Boga i zdolną oraz predysponowaną do nawiązania relacji z Nim.

7. Jest elementem, który jest inny od ciała, lecz w żaden sposób nie uderza w jedność osoby (bez tego elementu nie możemy nawet mówić o osobie, gdyż z punktu widzenia antropologii teologicznej relacyjność jest konstytutywną cechą osoby).

Powyższe wnioski wskazują, jakoby ujęcie relacyjne mogło pozostać jednocześnie niekolizyjne względem kompetencji neuronauk oraz zgodne z tezami antropologii teologicznej, a ponadto jest przystające względem tomistycznej metafizyki hylemorfizmu, w kluczu której formułowane były tezy Magisterium na temat ontologii duszy. To zaś stanowi nie tylko pozytywny prognostyk dialogu teologii i nauk, ale wskazuje, że zarówno obawy teologów jak i wnioski dyskredytujące pewne tezy teologiczne wyłaniające się z odkryć neuronauk są przedwczesne i nieuzasadnione. 
Słowa kluczowe: neuronauki, teologia, antropologia, metafizyka, dusza, nieśmiertelność, relacja.

\section{Bibliografia:}

1. Armstrong A.H., Markus R.A., Wiara chrześcijańska a filozofia grecka, tłum. H. Bednarek, Instytut Wydawniczy PAX, Warszawa 1964.

2. Benedykt XII, Konstytucja „Benedictus Deus”, [w:] Breviarium fidei: wybór doktrynalnych wypowiedzi Kościoła, I. Bokwa (red.), Księgarnia Świętego Wojciecha, Poznań 2007, s. 156-157.

3. Bremer J., Wprowadzenie do filozofii umystu, Wydawnictwo WAM, Kraków 2010.

4. Bremer J., Jažń i tożsamość osobowa, [w:] Przewodnik po filozofii umyshu, M. Miłkowski, R. Poczobut (red.), Wydawnictwo WAM, Kraków 2012, s. 427-462.

5. Brown W.S., Murphy N.C., Malony H.N., Whatever Happened to the Soul? Scientific and Theological Portraits of Human Nature, Fortress Press, Minneapolis 1998.

6. Chuderski A., Wykorzystanie metod sztucznej inteligencji w badaniach nad umystem, 3.06.2002, http://www.kognitywistyka.net/artykuly/ach-wmsiwnu.pdf, 27.02.2017.

7. Darowski R., Filozofia czlowieka: zarys problematyki, Wydawnictwo WAM, Kraków 2015.

8. Dawkins R., Ślepy zegarmistrz czyli jak ewolucja dowodzi, że świat nie został zaplanowany, tłum. A. Hoffman, Państwowy Instytut Wydawniczy, Warszawa 1997.

9. Dawkins R., Bóg urojony, tłum. P. Szwajcer, Wydawnictwo CiS, Warszawa 2007.

10. Dennett D.C., Odczarowanie: religia jako zjawisko naturalne, tłum. B. Stanosz, Państwowy Instytut Wydawniczy, Warszawa 2013.

11. Green J.B., What About the Soul?: Neuroscience and Christian Anthropology, Abingdon Press, Nashville 2004.

12. Iwanicki M., Dualizm psychofizyczny: odmiany, argumenty, zarzuty, [w:] Przewodnik po filozofii umystu, M. Miłkowski, R. Poczobut (red.), Wydawnictwo WAM, Kraków 2012, s. 37-84.

13. Johnson E.L., Whatever Happened to the Human Soul? A Brief, Christian Genealogy of a Psychological Term, "Journal of Psychology and Theology", 1998, t.26, nr 1, s. 16-28.

14. Kongregacja Nauki Wiary, List do biskupów o niektórych zagadnieniach dotyczacych eschatologii "Recentiores episcoporum Synodi", [w:] W trosce o pehnię wiary. Dokumenty Kongregacji Nauki Wiary 1966-1994, J. Królikowski (red.), tłum. J. Królikowski, Z. Zimowski, Wydawnictwo Biblos, Tarnów 1979, s. 129-132.

15. Kowalczyk S., Idea duszy w refleksji filozoficznej, Wydawnictwo KUL, Lublin 2016.

16. Liszka P., Dusza ludzka: substancja duchowa czlowieka, Wydawnictwo Tum, Wrocław 2017.

17. Martelet G., Odnalezione życie wieczne, tłum. M. Krzeptowska, Wydawnictwo WAM, Kraków 2000.

18. Miller P. D., Whatever Happened to the Soul?, "Theology Today", 1994, t.50, nr 4, s. 507-510.

19. Pabjan T., Anatomia konfliktu: Między nowym ateizmem a teologia nauki, Copernicus Center Press, Kraków 2016. 
20. Popper K.R., Eccles J.C., The self and its brain, Routledge, London 1990.

21. Ratzinger J., Eschatologia - śmierć $i$ życie wieczne, [w:] Zmartwychwstanie $i$ życie wieczne. Studia o eschatologii i teologii nadziei, tłum. J. Kobienia, Wydawnictwo KUL, Lublin 2014, s. 27-257.

22. Ruiz de La Peña J.L., Umysty, mózgi, maszyny, [w:] Kosmos $i$ człowiek, Wydawnictwo Pallottinum, Poznań-Warszawa 1989, t. 4, Kolekcja Communio, s. 156-170.

23. Rutowski T., Pojęcia materii na terenie filozofii i fizyki, „Studia Philosophiae Christianae", 1968, t. 23, nr 1, s. 75-96.

24. Seckler M., Zbawienie w historii. Teologia historii w nauce świętego Tomasza z Akwinu, tłum. W. Szymona, Fundacja „Dominikańskie Studium Filozofii i Teologii”: Kolegium Filozoficzno-Teologiczne Polskiej Prowincji Dominikanów, Kraków 2015.

25. Składanowski M., Ciało, dusza, duch. Myśl Josepha Ratzingera na tle wspótczesnej antropologii, Wydawnictwo Sióstr Loretanek, Warszawa 2013.

26. Smuniewski C., Wspólnota laski: charytologiczno-trynitarna eklezjogeneza, Wydawnictwo WAM, Kraków 2013.

27. Sobór Laterański V, Sesja 8 (piątek 5 maja 1513): I. Potępienie wszelkich twierdzeń sprzecznych z prawda chrześcijańskiej wiary objawionej na temat duszy ludzkiej, [w:] Dokumenty Soborów Powszechnych: tekst grecki, laciński, polski, t. 4, A. Baron, H. Pietras (red.), tłum. A. Baron, H. Pietras, A. Caba, Wydawnictwo WAM, Kraków 2003, s. 56-61.

28. Sobór w Vienne, Dekrety, [w:] Dokumenty Soborów Powszechnych: tekst grecki, łacinski, polski, t. 2, A. Baron, H. Pietras (red.), tłum. A. Baron, H. Pietras, T. Wnętrzak, Wydawnictwo WAM, Kraków 2003, s. 533-637.

29. Sobór Watykański II, Konstytucja dogmatyczna o Kościele „Lumen gentium”, [w:] Konstytucje, dekrety, deklaracje, Sobór Watykański II, Wydawnictwo Pallottinum, Poznań 2002, s. 104-166.

30. Sobór Watykański II, Konstytucja duszpasterska o Kościele „Gaudium et spes”, [w:] Konstytucje, dekrety, deklaracje, Sobór Watykański II, Wydawnictwo Pallottinum, Poznań 2002, s. 526-606.

31. Stenger V.J., God: the failed hypothesis; how science shows that good does not exist, Prometheus Books, Amherst - New York 2008.

32. Tomasz z Akwinu, Suma teologiczna, tłum. S. Bełch, Veritas, Londyn 1962.

33. Tomasz z Akwinu, Summa teologiczna: Traktat o człowieku I, 75-89, tłum. S. Swieżawski, Wydawnictwo Antyk, Kęty 1998.

34. Tresmontant C., Esej o myśli hebrajskiej, tłum. M. Tarnowska, Wydawnictwo Znak, Kraków 1996.

35. Turner D., Tomasz z Akwinu: portret, thum. M. Romanek, Wydawnictwo W drodze: Instytut Tomistyczny, Poznań - Warszawa 2017.

36. Wojciechowski T., Zagadnienie substancjalności duszy ludzkiej w ujęciu ewolucyjnym, „Roczniki Filozoficzne”, 1980, t.28, nr 3, s. 147-162.

37. Zeki S., Neurologia wieloznaczności, [w:] Formy aktywności umystu: ujęcia kognitywistyczne, A. Klawiter (red.), tłum. A. Gruszka, Wydawnictwo Naukowe PWN, Warszawa 2009, t. 2, Nowe Tendencje w Psychologii 14, s. 422-452. 